\title{
ODNOS UPRAVLJANJA RADNOM USPJEŠNOŠĆU I KOMPENZACIJSKOG MENADŽMENTA U VELIKIM PODUZEĆIMA U REPUBLICI HRVATSKOJ
}

\author{
Vinko Mostarac, mag. oec. \\ Hrvatska gospodarska komora \\ Adresa: Rooseveltov trg 2, Zagreb, Republika Hrvatska \\ E-mail: mo.s.7@hotmail.com \\ Danijel Knežević, mag. oec. \\ Europska poslovna škola Zagreb \\ Adresa: Selska cesta 119, Zagreb, Republika Hrvatska \\ E-mail: danijel.knezevic@zrinski.org \\ Ivan Budimir, mag. oec. \\ Hrvatska narodna banka \\ Adresa: Trg hrvatskih velikana 3, Zagreb, Republika Hrvatska \\ E-mail: ivan.budimir@hnb.hr
}

\section{SAŽETAK}

U suvremenim poduzećima jedan je od glavnih izazova pronaći način kako motivirati $i$ zadržati kvalitetne zaposlenike. Kako bi se u tome uistinu i uspjelo, poduzeća kontinuirano prate radnu uspješnost zaposlenika, a na temelju toga uvode i primjenjuju određene elemente sustava nagrađivanja. Glavni cilj ovog rada je istražiti sustav upravljanja radnom uspješnošću i koncept kompenzacijskog menadžmenta te njihov odnos u velikim poduzećima u Republici Hrvatskoj. U tu svrhu je provedeno anketno istraživanje na uzorku zaposlenika u velikim poduzećima u Republici Hrvatskoj. Nalazi istraživanja ukazuju na relevantnost i potrebu za daljnjim kontinuiranim razvojem i povezivanjem sustava praćenja radne uspješnosti i kompenzacijskog menadžmenta u poduzećima.

Ključne riječi: upravljanje radnom uspješnošću; kompenzacijski menadžment; velika poduzeća, Hrvatska 


\section{UVOD}

Odnos upravljanja radnom uspješnošću i kompenzacijskog menadžmenta važan je s aspekta cjelovitosti upravljanja radnom uspješnošću, ali i s aspekta svrsishodnosti kompenzacijskog menadžmenta. Cjelovit i kvalitetan sustav upravljanja radnom uspješnošću sastoji se od nekoliko elemenata koji trebaju biti međusobno povezani. Ako su svi elementi sustava upravljanja radnom uspješnošću prisutni, ali izostane nagrađivanje radne uspješnosti na temelju rezultata ocjene radne uspješnosti, tada će pozitivni efekti koje bi sustav upravljanja radnom uspješnošću mogao polučiti, vjerojatno izostati. Sama ocjena bez nagrade koja ju slijedi, može nerijetko djelovati i demotivirajuće i frustrirajuće za zaposlenika koji ju je ostvario. Istovremeno, zaposlenike sa slabijom radnom uspješnošću se ne motivira da se poboljšaju, jer znaju da za to neće biti nagrađeni, ali niti penalizirani. S druge strane, ako se razvijen i primjenjiv sustav nagrađivanja ne temelji na radnoj uspješnosti, teško je za očekivati da će poduzeće uspjeti motivirati i zadržati najbolje zaposlenike, a što bi trebao biti jedan od glavnih ciljeva. Upravo zbog potrebe za postojanjem veze između sustava upravljanja radnom uspješnošću i kompenzacijskog menadžmenta, proizlazi i hipoteza rada koja glasi: „Poduzeća koja imaju razvijen sustav upravljanja radnom uspješnošću imaju i razvijeniji sustav nagrađivanja od poduzeća koja nemaju upravljanje radnom uspješnošću. " Glavni cilj rada odnosi se na dokazivanje veze između upravljanja radnom uspješnošću i kompenzacijskog menadžmenta u velikim poduzećima u Republici Hrvatskoj, dok su pomoćni ciljevi: prikazati temeljne teorijske odrednice sustava upravljanja radnom uspješnošću, definirati koncept kompenzacijskog menadžmenta te prikazati važnost njihove povezanosti. Pretpostavka je da velika poduzeća, za razliku od ostalih, imaju u većoj mjeri razvijen sustav upravljanja radnom uspješnošću i sustav nagrađivanja koji proizlazi iz kompenzacijskog menadžmenta te zbog toga ona čine ciljanu populaciju ovog istraživanja. Za potrebe istraživanja razvijen je upitnik koji čini metodološku podlogu ovoga rada. Nakon uvodnog dijela, u drugom dijelu rada iznosi se teorijski prikaz sustava upravljanja radnom uspješnošću i koncepta kompenzacijskog menadžmenta te odnosa među njima. U trećem dijelu rada navodi se metodološki okvir provedenog istraživanja. Četvrti dio rada odnosi se na pregled nalaza empirijskog istraživanja o upravljanju radnom uspješnošću i kompenzacijskom menadžmentu u velikim poduzećima u Hrvatskoj. U zaključku su sažete temeljne teze i rezultati rada.

\section{TEORIJSKI OKVIR}

Teorijski okvir rada daje pregled definicija sustava upravljanja radnom uspješnošću, koncepta kompenzacijskog menadžmenta kao i objašnjenje povezanosti sustava upravljanja radnom uspješnošću i kompenzacijskog menadžmenta kako bi se zaokružio teorijski okvir problema istraživanja.

\subsection{Sustav upravljanja radnom uspješnošću}

U literaturi se mogu pronaći brojne definicije pojma upravljanja radnom uspješnošću, stoga su u nastavku navedene one najznačajnije. Upravljanje radnom uspješnošću odnosi se na sve menadžerske aktivnosti i instrumente, uključujući i procjenu uspješnosti, koji 
osiguravaju postizanje ciljeva uspješnosti i strategijskih ciljeva organizacije (BahtijarevićŠiber, 1999.).

Armstrong (2006.) smatra kako je upravljanje radnom uspješnošću sustavni proces poboljšavanja organizacijske radne uspješnosti razvijanjem radne uspješnosti pojedinaca i timova u organizaciji. Nadalje, navodi kako razumijevanje i upravljanje radnom uspješnošću unutar dogovorenog okvira planiranih ciljeva, standarda i zahtijevanih kompetencija, dovodi do boljih rezultata kako pojedinaca i timova, tako i organizacije u cjelini. Tvrdi da je to zajednički proces menadžera, pojedinaca i timova kojima oni upravljaju, a da procesi postoje za utvrđivanje onog što se treba postići te za upravljanje i razvoj ljudi u smjeru koji će povećati vjerojatnost da će se to i postići u kratkom i dugom roku.

Upravljanje radnom uspješnošću definira se kao strateški i integrirani proces koji se očituje u uspješnosti organizacije. Strateški je značajan, jer uključuje širu problematiku s kojima se organizacija susreće, ako će taj posao učinkovito obaviti i ići u smjeru postizanja dugoročnih ciljeva. Upravljanje radnom uspješnošću je integrirano upravljanje i javlja se u dva oblika integracije, u obliku okomite i u obliku vodoravne integracije. Okomita integracija povezuje ili usklađuje posao, a time i pojedinačne ciljeve u zajednički cilj. Vodoravna integracija uključuje povezivanje različitih aspekata menadžmenta ljudskih potencijala, posebno razvoja organizacije, nagrađivanje kadrova, a kako bi se postigao cjeloviti pristup menadžmenta u razvoju ljudi (Žilić, 2011.).

Upravljanje radnom uspješnošću je proces u kojem menadžeri i zaposlenici zajedno sudjeluju u izradi planova, praćenja i nadziranja radnih ciljeva zaposlenika i sveukupnog doprinosa organizaciji. Ono se ne ogleda samo u praćenju radne uspješnosti, već u motiviranju i angažiranju zaposlenika pružajući povratnu informaciju i mogućnost postavljanja ciljeva. Proces pomaže u usklađivanju ponašanja pojedinca s ciljevima organizacije, poboljšanju radnog okruženja i ispunjavanju želja zaposlenika za dobivanjem povratne informacije (HR Council, 2010.).

Nadalje, upravljanje radnom uspješnošću definira se kao proces kojim menadžeri osiguravaju da su aktivnosti i rezultati zaposlenika u skladu sa ciljevima organizacije. Sustav upravljanja uspješnošću sastoji se od tri dijela: definiranja radne uspješnosti, mjerenja radne uspješnosti te davanja povratne informacije o uspješnosti. Prvo, sustav upravljanja uspješnošću specificira koji su aspekti rada relevantni organizaciji, prvenstveno kroz analizu posla. Drugo, mjeri te aspekte procjenom radne uspješnosti, što je samo jedna od metoda mjerenja postignutih rezultata zaposlenika. Treće, daje zaposlenicima povratnu informaciju kroz sastanke o radnoj uspješnosti kako bi oni mogli prilagoditi svoj rad ciljevima organizacije (Križmarić, 2014.).

$\mathrm{Na}$ temelju navedenih definicija, može se reći da je upravljanje radnom uspješnošću sustavni proces koji je usmjeren na povezivanje individualnih i organizacijskih ciljeva kroz aktivnosti zajedničkog postavljanja ciljeva, praćenja i ocjenjivanja radne uspješnosti te dodatnog angažmana i uključivanja zaposlenika.

\subsection{Koncept kompenzacijskog menadžmenta}

Kompenzacijski menadžment podrazumijeva skup aktivnosti usmjerenih na istraživanje, oblikovanje, implementiranje i održavanje stimulativnih sustava naknada zaposlenicima za njihov rad i lojalnost organizaciji. Zadatak je kompenzacijskog menadžmenta osigurati 
adekvatan sustav nagrađivanja u organizacijama. Ključne grupe aktivnosti kompenzacijskog menadžmenta su istraživanje postojećih kompenzacijskih sustava, oblikovanje novog kompenzacijskog sustava, implementacija oblikovanog kompenzacijskog sustava te održavanje implementiranog kompenzacijskog sustava (Buble i Bakotić, 2013.).

Sustav upravljanja kompenzacijama mora biti oblikovan tako da bude u funkciji privlačenja, zadržavanja i motiviranja ljudi odgovarajućih znanja, vještina i sposobnosti koji će poduzeću omogućiti ostvarivanje definiranih ciljeva. Zbog toga je važno oblikovati sustav nagrađivanja koji je usklađen sa strategijom pojedine organizacije, odnosno sustav koji će uvažavati specifičnosti organizacije, ali koji će istovremeno biti motivirajući za zaposlenike (Tipurić et al., 2009.).

Sustav nagrađivanja jedan je od ključnih pokretača ponašanja zaposlenika u organizaciji te kao takav ima važnu ulogu u postizanju uspjeha ili neuspjeha organizacije u cjelini, kao i njenog napretka. Ono treba biti oblikovano da ohrabruje pojedince da posjeduju više informacija o poslu te, obogaćuju vlastite vještine, preuzmu odgovornost u donošenju odluka i rade na način koji poboljšava poslovne rezultate (Lawler, Mohrman i Benson, 2001.).

Unutar organizacije sustav nagrađivanja sastoji se od materijalnih i nematerijalnih kompenzacija, odnosno obuhvaća strategije materijalnog nagrađivanja i nematerijalne strategije motiviranja. Pod materijalnim kompenzacijama podrazumijevaju se izravne materijalne kompenzacije kao što su plaća, bonusi i poticaji, naknade za inovacije i širenje znanja, udio u profitu i vlasništvu te neizravne materijalne kompenzacije kao što su stipendije $i$ školarine, studijska putovanja, specijalizacije, automobili kompanije, osiguranja i zaštite, godišnji odmori i drugo. U nematerijalne kompenzacije ubrajaju se dizajniranje posla, stil managementa, participacija, upravljanje pomoću ciljeva, fleksibilno radno vrijeme i programi, priznanje i feedback, organizacijska kultura, usavršavanje i razvoj karijere i drugo (Bahtijarević-Šiber, 1999.).

Na temelju navedenog, kompenzacijski menadžment, odnosno upravljanje kompenzacijama, podrazumijeva cjelovitu izgradnju, oblikovanje i razvijanje sustava nagrađivanja u poduzeću, a koji bi bio usklađen s organizacijskih ciljevima, ali i s potrebama i očekivanjima zaposlenika.

\subsection{Povezanost sustava upravljanja radnom uspješnošću i kompenzacijskog menadžmenta}

Upravljanje radnom uspješnošću važan je dio sustava nagrađivanja jer pruža povratne informacije o realizaciji individualnih i timskih ciljeva te identificira prilike za rast i razvoj. Bavi se mjerenjem outputa u svrhu usporedbe ostvarene radne uspješnosti s očekivanjima izraženima kroz ciljeve. U tom se pogledu upravljanje radnom uspješnošću fokusira na ciljeve, standarde i mjere odnosno indikatore radne uspješnosti. Ono zahtijeva neprestani razgovor o radnoj uspješnosti, što uključuje zajedničko i kontinuirano ispitivanje postignuća što se tiče ciljeva, zahtjeva i planova. Zbog toga se upravljanje radnom uspješnošću temelji na dogovoru koji obuhvaća obaveze svakog pojedinca, postavljene ciljeve, unapređenje radne uspješnosti i planove osobnog razvoja (Galetić, 2012.).

Kako je prisutan trend rasta varijabilnog dijela (baziranog na radnom učinku) u ukupnim nagradama, tako i upravljanje radnom uspješnošću poprima važnu ulogu u ukupnom 
sustavu nagrađivanja. Kvalitetan sustav upravljanja radnom uspješnošću čini temelj za jednako kvalitetan sustav kompenzacija. Upravljanje radnom uspješnošću sastoji se od brojnih dimenzija te daje mnoštvo relevantnih informacija za kvalitetno odlučivanje u gotovo svim aspektima menadžmenta ljudskih potencijala, pa tako, između ostalog, služi i za donošenje kvalitetnih odluka u svezi s nagrađivanjem. Na taj način, nagrađivanje se povezuje s uspješnošću te se time osigurava poticajni (stimulativni) sustav nagrađivanja. Sustav nagrađivanja se stavlja u funkciju povećanja radnog učinka i radne uspješnosti ukoliko su nagrade povezane uz one pokazatelje radne uspješnosti na koje pojedinac ili grupa može utjecati svojim ponašanjem i rezultatima rada. Naglašava se važnost postojanja jasne veze između rezultata rada i nagrada, odnosno nagrade vezane za veći učinak i bolju radnu uspješnost moraju neposredno slijediti povećane rezultate. Sustav nagrađivanja u kojem je nagrada bazirana na ostvarenom radnom učinku (dijelom ili u potpunosti) ima veći potencijal motivirati zaposlenike da efikasnije i efektivnije izvršavaju svoje zadatke i obveze na radnom mjestu. Nagrade trebaju biti dovoljno velike kako bi bile percipirane kao primjerene uloženom trudu te kao fer i pravične u usporedbi s drugima unutar i izvan organizacije te s drugim organizacijama i tržištem. To dovodi do postojanja stimulativnog sustava nagrađivanja kojeg odlikuje postojanje jasnih standarda radnog izvršenja i uspješnosti, razumijevanje i opće prihvaćanje načina utvrđivanja radne uspješnosti te načina nagrađivanja i vrednovanja. Posebice je bitno da zaposlenici budu upoznati sa standardima i načinom mjerenja, odnosno, da ih u potpunosti razumiju i da budu svjesni da su pod njihovim utjecajem te da svojim sposobnostima i ponašanjem mogu djelovati na njih. Ukoliko standardi nisu jasno prikazani ili određeno postignuće nije pravedno nagrađeno, pojavljuje se demotivacija i nezadovoljstvo zaposlenika što može biti prijetnja daljnjem razvoju organizacije. Dakle, važna je i transparentnost kao i postojanje povjerenja posebice između menadžera i izvršitelja te sigurnost da veći učinak neće voditi podizanju standarda nego naprotiv, većim materijalnim primanjima i/ili drugim oblicima nagrađivanja i motiviranja zaposlenika (Bahtijarević-Šiber, 1999.; Lawler, Mohrman i Benson, 2001.; Pettinger, 2010.).

Dakle, aktivnosti procesa upravljanja radnom uspješnošću jedan su od osnovnih preduvjeta za uspješnu implementaciju cjelokupnog kompenzacijskog sustava. Ono doprinosi donošenju objektivnih i kvalitetnih odluka od strane menadžera. Omogućuje zaposlenicima dobivanje pravodobnih povratnih informacija o radnoj uspješnosti te povezanosti i utjecaju na dobivene nagrade. Takav sustav doprinosi i potencijalnom unapređenju rada i boljoj radnoj uspješnosti pojedinaca, timova, a time i uspješnosti cijele organizacije.

Upravljanje radnom uspješnošću i kompenzacijski menadžment su pojmovi koji se ne bi trebali promatrati odvojeno jedno od drugog. Dapače, kao što je navedeno, aktivnosti procesa upravljanja radnom uspješnošću trebaju biti temelj, odnosno baza ukupnog sustava nagrađivanja. Njihovo kvalitetno provođenje, odnosno implementacija, velik je korak prema adekvatnom i pravednom sustavu kompenzacija u organizaciji te ujedno i doprinosi ostvarenju pojedinih funkcija, tj. aktivnosti menadžmenta ljudskih potencijala u organizacijama. 


\section{METODOLOŠKI OKVIR ISTRAŽIVANJA}

Svako znanstveno istraživanje polazi od određenog znanstvenoga pristupa iz kojeg proizlazi metodološki okvir istraživanja. U okviru ovog dijela rada objašnjava se metodologija prikupljanja i obrade podataka te se opisuje uzorak na kojem će se provoditi istraživanje.

\subsection{Prikupljanje i obrada podataka}

Metoda prikupljanja podataka za potrebe ovog istraživanja bila je anketa. Anketa je najčešće korištena tehnika prikupljanja podatka u društvenim istraživanjima, osobito pogodna za opisna i uzročna istraživanja (Tkalac Verčić, Sinčić Ćorić i Pološki Vokić, 2013.). Upitnik koji je izrađen za potrebe ovog istraživanja sastojao se od 20 pitanja.

Prvi dio pitanja u upitniku odnosio se na ispitivanje pojedinaca o upoznatosti sa značenjem pojmova upravljanje radnom uspješnošću i kompenzacijski menadžment te prepoznavanjem elemenata istih u poduzećima u kojima su zaposleni. Drugi dio upitnika obuhvaćao je pitanja koja su vezana uz obilježja samih ispitanika (spol, dob, visina dohotka, stručna sprema i radno iskustvo), a koja omogućuju njihovu segmentaciju. Također, upitnik je sadržavao pitanja vezana uz vrstu organizacije u kojoj je ispitanik zaposlen, a pri tome su korištene varijable: vlasništvo, djelatnost i broj zaposlenika. Korišten je online upitnik koji je distribuiran ispitanicima putem online poveznice na kojoj je bilo omogućeno popunjavanje upitnika i sudjelovanje u istraživanju. Podaci su se prikupljali tijekom 2019. godine. Prikupljeni podaci obrađeni su u programu Excel (sastavni dio Microsoft Office programskog paketa), a za prikaz rezultata korišteni su grafikoni. Pri izradi grafikona, a radi preglednosti, elementi (odgovori ispitanika) koji nisu bili zastupljeni (nula odgovora), nisu prikazani.

\subsection{Uzorak}

Uzorak poduzeća proizlazi iz popisa svih poduzeća u Hrvatskoj dostupnih unutar baze Hrvatske gospodarske komore. Okvir uzorka čine sva poduzeća u Hrvatskoj koja su klasificirana kao velika te su na dan pretrage bila u aktivnom statusu (Hrvatska gospodarska komora, Baza poslovnih subjekata). Predmetni kriteriji su odabrani, jer se pretpostavlja da velika poduzeća, za razliku od ostalih, imaju u većoj mjeri razvijen sustav upravljanja radnom uspješnošću i sustav nagrađivanja koji proizlazi iz kompenzacijskog menadžmenta. Navedene kriterije su zadovoljila ukupno 474 poduzeća.

$\mathrm{U}$ istraživanju je sudjelovalo 59 ispitanika iz jednako toliko poduzeća, jer je namjera autora bila da u istraživanju sudjeluje samo po jedan zaposlenik iz pojedinog poduzeća iz uzorka. Ispitani uzorak poduzeća čini nešto više od $12 \%$ svih velikih poduzeća u Hrvatskoj.

Budući da su se u upitniku nalazila i socio-ekonomska pitanja vezana uz obilježja pojedinog ispitanika te da je temeljem toga moguća segmentacija istih, u nastavku je prikazan profil ispitanika koji su sudjelovali u istraživanju (Tablica 1). 
Tablica 1. Profil ispitanika

Varijabla segmentacije

Udio u uzorku

\begin{tabular}{|c|c|c|}
\hline \multirow{2}{*}{ Spol } & $\mathrm{M}$ & $54 \%$ \\
\hline & $\check{Z}$ & $46 \%$ \\
\hline \multirow{5}{*}{ Dob } & Od 18 do 29 godina & $20 \%$ \\
\hline & Od 30 do 39 godina & $54 \%$ \\
\hline & Od 40 do 49 godina & $15 \%$ \\
\hline & Od 50 do 64 godina & $10 \%$ \\
\hline & 65 i više & $0 \%$ \\
\hline \multirow{6}{*}{ Visina mjesečnog dohotka } & do 5.000 HRK & $5 \%$ \\
\hline & od 5.001 do $7.000 \mathrm{HRK}$ & $31 \%$ \\
\hline & od 7.001 do $10.000 \mathrm{HRK}$ & $37 \%$ \\
\hline & od 10.001 do $15.000 \mathrm{HRK}$ & $15 \%$ \\
\hline & od 15.001 do $20.000 \mathrm{HRK}$ & $5 \%$ \\
\hline & 20.001 HRK i više & $7 \%$ \\
\hline \multirow{6}{*}{ Stručna sprema } & NKV & $0 \%$ \\
\hline & SSS & $20 \%$ \\
\hline & VŠS & $15 \%$ \\
\hline & VSS & $44 \%$ \\
\hline & Magisterij & $20 \%$ \\
\hline & Doktorat & $0 \%$ \\
\hline \multirow{5}{*}{ Ukupno radno iskustvo } & manje od 3 godine & $7 \%$ \\
\hline & od 3 do 5 godina & $32 \%$ \\
\hline & od 6 do 10 godina & $27 \%$ \\
\hline & od 11 do 20 godina & $17 \%$ \\
\hline & 21 godina i više & $17 \%$ \\
\hline \multirow{5}{*}{ Radno iskustvo u trenutnom poduzeću } & manje od 3 godine & $20 \%$ \\
\hline & od 3 do 5 godina & $37 \%$ \\
\hline & od 6 do 10 godina & $20 \%$ \\
\hline & od 11 do 20 godina & $14 \%$ \\
\hline & 21 godina i više & $9 \%$ \\
\hline
\end{tabular}

Izvor: Izrada autora

Kao što je vidljivo iz prikaza profila ispitanika, u ispitanom uzorku prevladavaju muškarci, od 30 do 39 godina, s mjesečnim dohotkom u iznosu od 7.001,00 do 10.000,00 HRK, visoke stručne spreme, s ukupnim radnim iskustvom od 3 do 5 godina i jednakim radnim iskustvom u poduzeću u kojem su trenutno zaposleni. 


\section{EMPIRIJSKO ISTRAŽIVANJE ODNOSA UPRAVLJANJA RADNOM USPJEŠNOŠĆU I KOMPENZACIJSKOG MENADŽMENTA U VELIKIM PODUZEĆIMA U HRVATSKOJ}

Kao što je već ranije spomenuto, u istraživanju je sudjelovalo 59 ispitanika (zaposlenika) iz jednakog broja i poduzeća. Dakle, svako poduzeće je predstavljao jedan ispitanik, odnosno zaposlenik tog poduzeća. Slijedom korištenja varijabli za segmentaciju poduzeća, dobiveni su rezultati prikazani u nastavku (Grafikon 1, Grafikon 2 i Grafikon 3).

\section{Grafikon 1 Poduzeća prema obliku vlasništva}

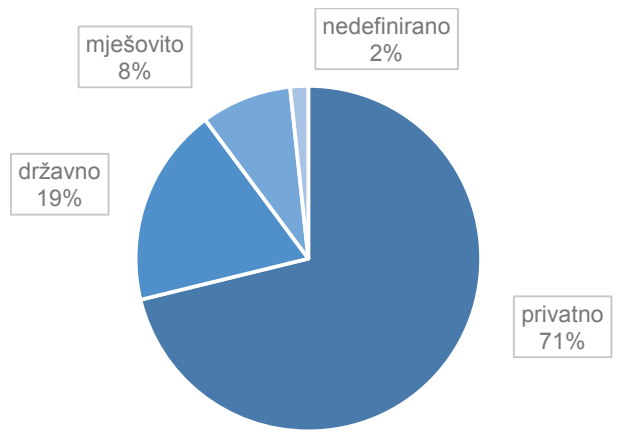

Izvor: Izrada autora

Prema obliku vlasništva, u uzorku je bilo 71\% privatnih poduzeća, $19 \%$ državnih, $8 \%$ mješovitih, $2 \%$ nedefiniranih te nijedno zadružno poduzeće.

\section{Grafikon 2 Primarna djelatnost poduzeća prema NKD 2007.}

Financijske djelatnosti i djelatnosti osiguranja Informacije i komunikacije Trgovina na veliko i na malo; popravak motornih vozila.

Opskrba električnom energijom, plinom, parom i..

Ostale uslužne djelatnosti

Prerađivačka industrija

Poljoprivreda, šumarstvo i ribarstvo Administrativne i pomoćne uslužne djelatnosti

Građevinarstvo

Opskrba vodom; uklanjanje otpadnih voda,

Djelatnosti izvanteritorijalnih organizacija i tijela

Djelatnosti pružanja smještaja te pripreme i usluživanja.

Javna uprava i obrana; obvezno socijalno osiguranje

Prijevoz i skladištenje

Stručne, znanstvene i tehničke djelatnosti

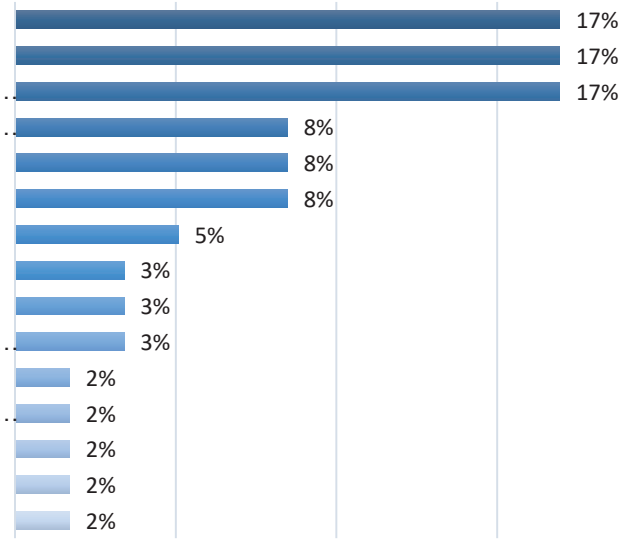

Izvor: Izrada autora 
Razmatrajući primarnu djelatnost poduzeća iz uzorka, prema Nacionalnoj klasifikaciji djelatnosti 2007., vidljivo je da je najveći broj poduzeća iz tri glavne djelatnosti: financijske djelatnosti i djelatnosti osiguranja (17\%), informacije i komunikacije (17\%) te trgovina na veliko i na malo; popravak motornih vozila i motocikla (17\%).

\section{Grafikon 3 Poduzeća prema broju zaposlenika}

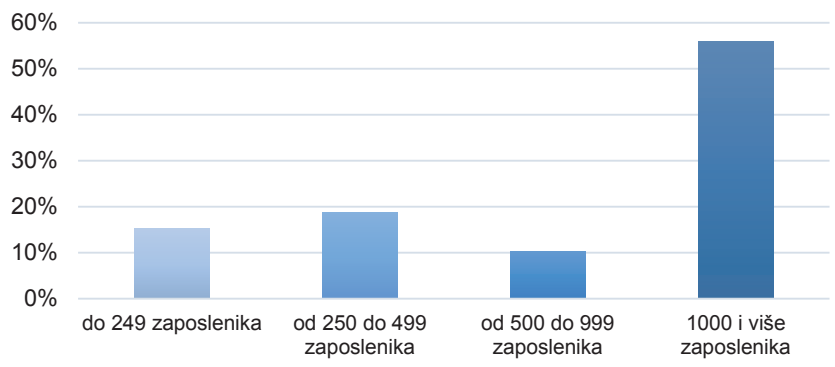

Izvor: Izrada autora

lako se sva poduzeća iz uzorka klasificiraju kao velika poduzeća, uvođenjem varijable broj zaposlenika, omogućen je detaljniji prikaz poduzeća u istraživanju. Više od polovice poduzeća iz uzorka broji 1000 i više zaposlenika (56\%), a najmanje je poduzeća s rasponom broja zaposlenika od 500 do 999 (10\%).

Nakon što je prikazana segmentacija poduzeća iz uzorka prema određenim varijablama, u nastavku je grafički prikaz odgovora ispitanika temeljenih na njihovoj percepciji stanja vezano uz sustav upravljanja radnom uspješnošću i koncept kompenzacijskog menadžmenta u poduzećima gdje su zaposleni (Grafikon 4., Grafikon 5., Grafikon 6., Grafikon 7. i Grafikon 8.).

Potrebno je istaknuti da je čak 78\% ispitanika bilo upoznato s pojmom upravljanje radnom uspješnošću prije ovog istraživanja, od čega je većina njih čula za pojam u organizaciji u kojoj su zaposleni. Svi anketirani ispitanici smatraju važnim ili izrazito važnim upravljanje radnom uspješnošću.

\section{Grafikon 4 Postojanje sustavnog upravljanja radnom uspješnošću u poduzećima}

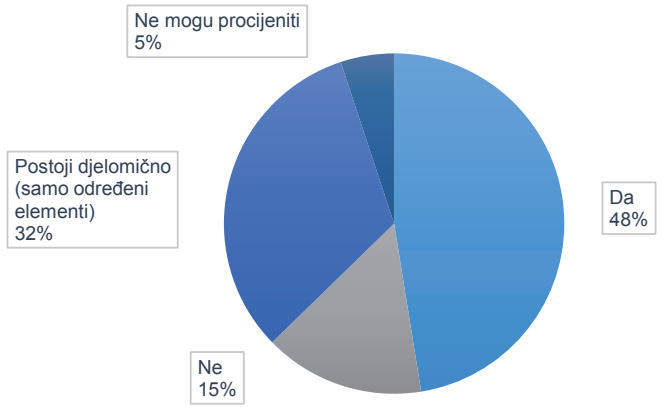

Izvor: Izrada autora 
U čak $80 \%$ ispitanih poduzeća postoji (barem djelomično) sustavno upravljanje radnom uspješnošću. Dodatno, vezano uz ispitivanje osoba/odjela uključenih u implementaciju sustava upravljanja radnom uspješnošću unutar poduzeća, njih 39\% je navelo da je to menadžment, a $24 \%$ ispitanika je navelo odjel ljudskih potencijala. U $19 \%$ poduzeća svi su zaposlenici uključeni u implementaciju sustava upravljanja radnom uspješnošću.

\section{Grafikon 5 Učinkovitost sustava upravljanja radnom uspješnošću u poduzećima}

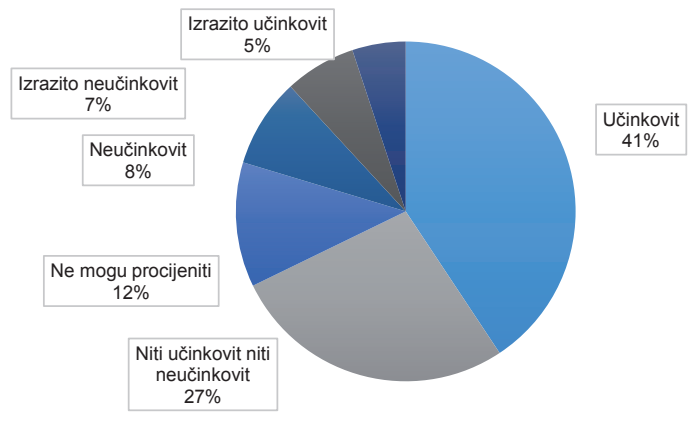

Izvor: Izrada autora

Pri ispitivanju o (ne)učinkovitosti sustava upravljanja radnom uspješnošću, njih 41\% smatra da je sustav upravljanja radnom uspješnošću u njihovom poduzeću učinkovit, a $27 \%$ ih smatra niti učinkovitim niti neučinkovitim; $8 \%$ ih smatra neučinkovitim, a $7 \%$ izrazito neučinkovitim; samo $5 \%$ ispitanih smatra da je u njihovom poduzeću izrazito učinkovit sustav upravljanja radnom uspješnošću.

\section{Grafikon 6 Postojanje koncepta kompenzacijskog menadžmenta u poduzećima}

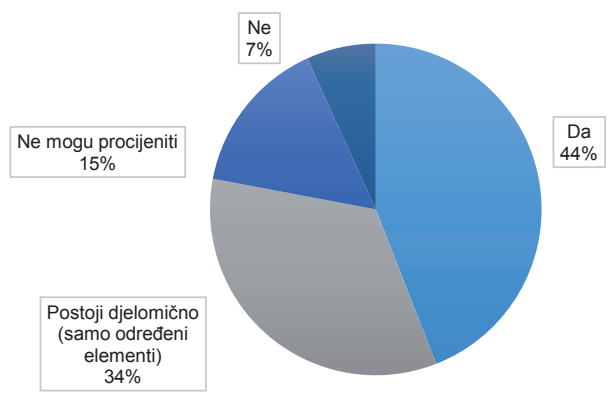

Izvor: Izrada autora

U čak 78\% ispitanih poduzeća postoji (barem djelomično) i prepoznaje se koncept kompenzacijskog menadžmenta, odnosno sustav upravljanja kompenzacijama; za 7\% poduzeća navodi se da koncept kompenzacijskog menadžmenta, kao takav, ne postoji. 


\section{Grafikon 7 Jasnoća i transparentnost sustava upravljanja kompenzacijama u poduzećima}

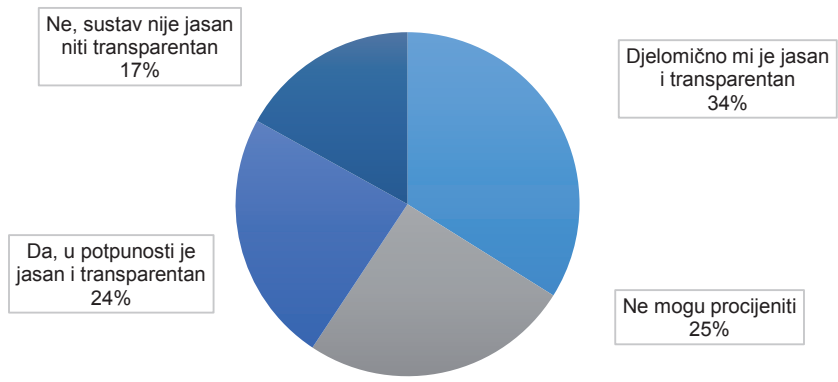

Izvor: Izrada autora

Samo je $24 \%$ ispitanika navelo da je sustav upravljanja kompenzacijama u njihovom poduzeću jasan i transparentan, dok je njih 34\% navelo da je djelomično jasan i transparentan; $17 \%$ ispitanika je navelo da im sustav upravljanja kompenzacijama u njihovim poduzećima nije niti jasan niti transparentan.

\section{Grafikon 8 Elementi materijalnih kompenzacija u poduzećima}

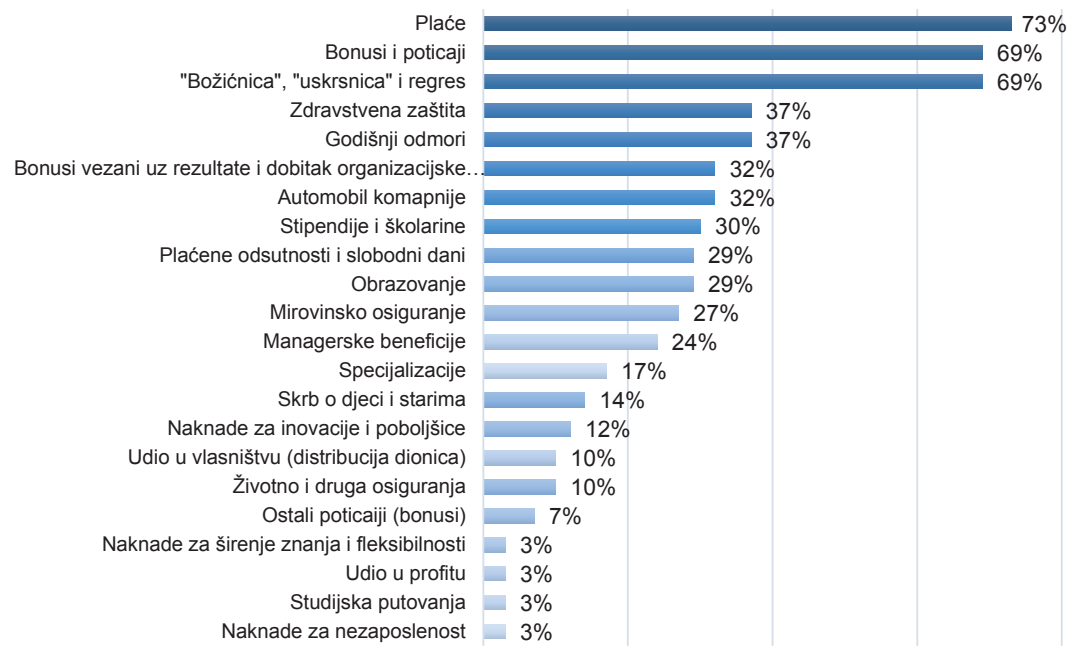

Izvor: Izrada autora

Prema elementima materijalnih kompenzacija u poduzećima, u najvećem broju poduzeća su zastupljene plaće sa 73\%. Nakon plaća, slijede bonusi i poticaji kao i „božićnica“, „uskrsnica“ i regres koje isplaćuje 69\% poduzeća. Najmanji dio poduzeća, samo njih 3\%, pruža svojim zaposlenicima naknade za širenje znanja i fleksibilnosti, udio u profitu, studijska putovanja i naknade za nezaposlenost. 


\section{Grafikon 9 Povezanost sustava upravljanja radnom uspješnošću i koncepta kompenzacijskog menadžmenta u poduzećima}

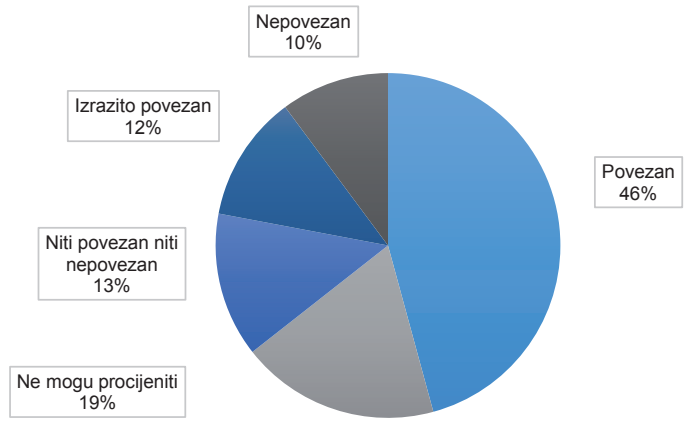

Izvor: Izrada autora

Od svih ispitanika, njih 58\% smatra da u njihovim poduzećima postoji povezanost između sustava upravljanja radnom uspješnošću i koncepta kompenzacijskog menadžmenta; njih 19\% ne može procijeniti postoji li povezanost; $13 \%$ ispitanika smatra niti povezanim niti nepovezanim, dok $10 \%$ ispitanika jasno navodi da u njihovim poduzećima ne postoji povezanost između sustava upravljanja radnom uspješnošću i koncepta kompenzacijskog menadžmenta. Nijedan ispitanik nije naveo da postoji izrazita nepovezanost između sustava upravljanja radnom uspješnošću i koncepta kompenzacijskog menadžmenta u poduzećima u kojima su zaposleni.

Kako bi se potvrdila postavljena hipoteza provedena je statistička analiza podataka prikazanih na grafikonima 4 i 8 (odnosno podataka o postojanju sustavnog upravljanja radnom uspješnošću i broju elemenata materijalnih kompenzacija u poduzećima).

Tablica 2 Odabrani statistički pokazatelji o broju elemenata materijalnih kompenzacija prema sustavnosti upravljanja radnom uspješnošću u poduzeću

\begin{tabular}{|l|c|c|c|c|}
\hline & $\begin{array}{c}\text { Poduzeća koja } \\
\text { imaju sustavno } \\
\text { upravljanje radnom } \\
\text { uspješnošću }\end{array}$ & $\begin{array}{c}\text { Poduzeća } \\
\text { koja nemaju } \\
\text { uspravješnošću } \\
\text { uspje radnom }\end{array}$ & $\begin{array}{c}\text { Poduzeća u } \\
\text { kojima postoji } \\
\text { djelomično (samo } \\
\text { određeni elementi) } \\
\text { upravljanje radnom } \\
\text { uspješnošću }\end{array}$ & $\begin{array}{c}\text { Poduzeća u } \\
\text { kojima se nije } \\
\text { mogla procijeniti } \\
\text { sustavnost } \\
\text { upravljanje radnom } \\
\text { uspješnošću }\end{array}$ \\
\hline Prosjek & 6 & 3 & 7 & 3 \\
\hline Mod & 2 & 1 & 6 & 2,3 i 4 \\
\hline Medijan & 6 & 2 & 6 & 3 \\
\hline Minimum & 1 & 1 & 15 & 2 \\
\hline Maksimum & 16 & 6 & 1 & 4 \\
\hline
\end{tabular}

Izvor: Izrada autora 
Prema podacima iz tablice vidljiva je razlika u prosječnom broju elemenata materijalnih kompenzacija koja imaju poduzeća sa sustavnim (6) i djelomičnim upravljanjem radnom uspješnošću (7) u odnosu na poduzeća koja nemaju upravljanje radnom uspješnošću. Također, razlike se vide i kod medijalne vrijednosti i maksimalnog broja elemenata koje materijalnih kompenzacija koje poduzeća s obzirom na sustavnost upravljanja radnom uspješnošću koriste. Razlika se može uočiti u svim pokazateljima, osim u pokazatelju najmanjeg broja elemenata materijalnih kompenzacija gdje među svim promatranim poduzećima mogu pronaći poduzeća koja imaju samo 1 element materijalnih kompenzacija. Iz svega navedenog se može zaključiti da je postavljena hipoteza većim dijelom dokazana.

\section{ZAKLJUČAK}

Upravljanje radnom uspješnošću i kompenzacijski menadžment pojmovi su koji se ne bi trebali promatrati odvojeno jedno od drugog. Dapače, aktivnosti procesa upravljanja radnom uspješnošću trebaju biti temelj, odnosno baza ukupnog sustava nagrađivanja. Njihovo kvalitetno provođenje, odnosno implementacija, velik je korak prema adekvatnom i pravednom sustavu kompenzacija u organizaciji te ujedno i doprinosi ostvarenju pojedinih funkcija, tj. aktivnosti menadžmenta ljudskih potencijala u organizacijama.

Provedeno empirijsko istraživanje daje uvid u stanje sustava upravljanja radnom uspješnošću i kompenzacijskog menadžmenta u velikim poduzećima u Hrvatskoj. Pokazalo se da su zaposlenici relativno dobro upoznati s navedenim pojmovima te da postoji svijest o važnosti istih. U 80\% ispitanih poduzeća postoji (barem djelomično) sustavno upravljanje radnom uspješnošću u čiju su primjenu većinom uključeni menadžment i odjel ljudskih potencijala. Nešto manje od polovice ispitanika smatra da je sustav upravljanja radnom uspješnošću u njihovim poduzećima učinkovit, a njih 15\% smatra da je neučinkovit. U 78\% ispitanih poduzeća postoji (barem djelomično) i prepoznaje se koncept kompenzacijskog menadžmenta. Samo $24 \%$ ispitanika navelo je da je sustav upravljanja kompenzacijama u njihovom poduzeću potpuno jasan i transparentan. Konačno, $58 \%$ ispitanika smatra da u njihovim poduzećima postoji povezanost između sustava upravljanja radnom uspješnošću i koncepta kompenzacijskog menadžmenta, dok $10 \%$ ispitanika jasno navodi da u njihovim poduzećima ne postoji povezanost između sustava upravljanja radnom uspješnošću i koncepta kompenzacijskog menadžmenta. Navedeno upućuje da u velikim poduzećima u Hrvatskoj postoji povezanost upravljanja radnom uspješnošću i kompenzacijskog menadžmenta, no da još postoji prostor za izgradnju odnosa kako bi svim zaposlenicima bio jasniji i transparentniji te relevantan za poduzimanje pojedinih aktivnosti. $U$ radu je također prikazana i analiza kojom se većim dijelom dokazuje hipoteza da poduzeća koja imaju razvijen sustav upravljanja radnom uspješnošću imaju i razvijeniji sustav nagrađivanja od poduzeća koja nemaju upravljanje radnom uspješnošću

Kao i većina empirijskih istraživanja, tako i ovo istraživanje ima svoja ograničenja. Kao prvo ograničenje može se navesti činjenica da je u istraživanju sudjelovalo tek nešto više od $12 \%$ od ukupnog broja velikih poduzeća u Hrvatskoj te da poduzeća nisu ravnomjerno zastupljena po djelatnostima. Kao drugo ograničenje može se navesti da su u istraživanju pretežno sudjelovali ispitanici sa područja grada Zagreba i okolice, relativno mlađe do srednje životne dobi te koji su u trenutku provođenja istraživanja bili dostupni, a imajući u vidu da su zaposlenici velikih poduzeća. 
Iz svega iznesenog razvidno je da dobiveni rezultati provedenog istraživanja mogu biti indikativni za stručnjake u pojedinim poduzećima radi poduzimanja određenih aktivnosti s ciljem razvoja i povezivanja sustava upravljanja radnom uspješnošću i kompenzacijskog menadžmenta. Također, nalazi ovog istraživanja mogu biti temelj za provođenje složenijih i obuhvatnijih istraživanja iz predmetnog područja u budućnosti. 


\title{
THE RELATIONSHIP BETWEEN PERFORMANCE MANAGEMENT AND COMPENSATION MANAGEMENT IN LARGE COMPANIES IN THE REPUBLIC OF CROATIA
}

\author{
Vinko Mostarac, MSc \\ Croatian Chamber of Economy \\ Rooseveltov trg 2, Zagreb, Croatia \\ E-mail: mo.s.7@hotmail.com \\ Danijel Knežević, MSc \\ European Business School Zagreb \\ Selska cesta 119, Zagreb, Croatia \\ E-mail: danijel.knezevic@zrinski.org \\ Ivan Budimir, MSc \\ Croatian National Bank \\ Trg hrvatskih velikana 3, Zagreb, Croatia \\ E-mail: ivan.budimir@hnb.hr
}

\begin{abstract}
In modern companies, one of the main challenges is finding a way to motivate and retain quality employees. In order to truly achieve this goal, companies continuously monitor employees' work performance and, on that basis, introduce and apply certain elements of a reward system. The main objective of this paper is to explore the performance management system and the concept of compensation management and ultimately their relationship in large companies in the Republic of Croatia. For this purpose, a survey was conducted on the sample of employees in large companies in the Republic of Croatia. The findings of the research imply the relevance and requisite for further continuous development and integration of a performance management system and compensation management in companies.
\end{abstract}

Keywords: performance management; compensation management; large companies; Croatia 


\section{LITERATURA}

1. Armstrong, M. (2006). Performance management: Key strategies and practical guidelines. London and Philadelphia: Kogan Page.

2. Pfeifer, S. (2008). Upravljanje radnom uspješnošću. Osijek: Ekonomski fakultet [online]. Dostupno na http://www.efos.unios.hr/arhiva/dokumenti/8.\%20predavanje\%20MLJR.pdf [15. veljače 2020.]

3. Tipurić, D. et al. (2009). Strateške inicijative za unaprjeđenje poslovanja Hrvatskih šuma d.o.o. Zagreb: Ekonomski fakultet [online]. Dostupno na https://www.sumari.hr/biblio/pdf/14090-3. pdf [15. veljače 2020.]

4. Tkalac Verčić, A., Sinčić Ćorić, D. i Pološki Vokić, N. (2013). Priručnik za metodologiju istraživačkog rada u društvenim istraživanjima. Zagreb: M.E.P.

5. Žilić, I. (2011). Utjecaj strategija poslovne izvrsnosti na performanse hotela u Republici Hrvatskoj. Split: Ekonomski fakultet.

6. Bahtijarević-Šiber, F. (1999). Management ljudskih potencijala. Zagreb: Golden Marketing.

7. Buble, M. i Bakotić, D. (2013.) Kompenzacijski menadžment. Split: Ekonomski fakultet.

8. Galetić, L. (2012). Izabrane teme iz kompenzacijskog menadžmenta. Zagreb: Ekonomski fakultet.

9. HR Council for the Nonprofit Sector (2010). Trends \& Issues: The Art of Performance Management, nonprofit style. [online]. Dostupno na http://www.hrcouncil.ca/documents/LMI_performance_management.pdf [15. veljače 2020.]

10. Hrvatska gospodarska komora, Baza poslovnih subjekata. [online]. Dostupno na https://digitalnakomora.hr/home [17. kolovoza 2018.]

11. Križmarić, Ž. (2014). Strateški menadžment u korelaciji s upravljanjem radnom uspješnošću i oblikovanjem poslova. Tehnički glasnik, 8(1), 48-52.

12. Lawler, E. E., Mohrman, S. A. i Benson, G. (2001). Organizing for high performance: employee involvement, TQM, reengineering, and knowledge management in the Fortune 1000. San Francisco: Jossey-Bass.

13. Pettinger, R. (2010). Organizational behaviour: performance management in practice. Abingdon: Routledge. 